\title{
Organisatoriese doeltreffendheid in Suid-Afrika en Japan
}

\author{
H.J.J. Spoelstra \\ Skool vir Bedryfsleiding, Universiteit van Suid-Afrika
}

\begin{abstract}
Organizational effectiveness In South Africa and Japan. Japan's extraordinary economic success of the past century makes it an excellent source of comparison with South Africa where economic success is still hampered by problems such as low productivity, unemployment and organizational ineffectiveness. In Japan the principles of utilization of manpower are based on the high priority given to labour as a factor of production. The life-time employment system, life-time training and seniority as motive for promotion and remuneration are examples of labour deployment. Decisions are initiated at the lowest levels and only arrived at by concensus while the only role of management is to maintain harmony during the process. Individual work input is high and labour unions play an important and supportive role in the effective functioning of organizations.

S. Afr. J. Bus. Mgmt. 1981, 12: $14-21$
\end{abstract}

Die besondere sukses van die Japanse ekonomie gedurende die afgelope eeu maak dié land 'n uitstekende bron van vergelyking met Suid-Afrika waar ekonomiese sukses nog relatief laag is as gevolg van probleme soos lae produktiwiteit, werkloosheid en organisatoriese doeltreffendheid. In Japan word arbeidsbenuttingsbeginsels gefundeer in die besondere prioriteit wat aan arbeid as produksiefaktor toegeskryf word. Lewenslange indiensneming, lewenslange opleiding en die senioriteitsbeginsel by bevordering en vergoeding is voorbeelde van die benutting van arbeid. Besluite word op die laagste vlakke geinisieer en slegs deur konsensus bereik. Bestuur sien slegs toe dat harmonie in die proses gehandhaaf word. Individuele werkinset is hoog en vakbonde speel ' $n$ belangrike en ondersteunende rol in die doeltreffende funksionering van organisasies.

S.-Afr. Tydskr. Bedryfsl. 1981, 12: 14- 21
In 'n studie deur Spoelstra, ${ }^{1}$ is 'n intensiewe vergelyking van organisatoriese doeltreffendheid in Suid-Afrika en in Japan gemaak. Daarbenewens is ondersoek ingestel na die faktore wat vir die bestaande doeltreffendheidsvlak verantwoordelik is. In hierdie verband is veral op aspekte soos gebruike en praktyke binne organisasies, arbeidstelsels, arbeidsfilosofie en kultuur gekonsentreer.

Japan is as bron van vergelyking uitgesonder omdat dié land in toenemende mate, weens sy ekonomiese prestasies van die afgelope eeu, as seker die doeltreffendste ekonomie ter wêreld uitgesonder word. Westerse navorsers stel al hoe meer belang in dié aspekte wat vir die land se groot ekonomiese voorspoed en kulturele welvaart verantwoordelik is.

Die beperkte ruimte van hierdie artikel laat dit nie toe dat al die fasette van die Japanese suksesverhaal behandel kan word nie. Dit is ook nie moontlik om hier al die resultate van die ondersoek, (waarna hierbo verwys is) te bespreek nie. Daar sal gevolglik slegs gepoog word om enkele elemente van organisatoriese doeltreffendheid in Suid-Afrika en in Japan te vergelyk, terwyl die determinante van organisatoriese doeltreffendheid, in 'n latere artikel behandel sal word.

In onlangse jare, en veral ook sedert die ekonomiese opkoms van ander lande in die wêreld, word die doeltreffendheid van Westerse riglyne en beginsels vir SuidAfrikaanse organisasies toenemend bevraagteken.

Japan word uitgesonder as ' $n$ unieke en stimulerende bron van vergelyking in hierdie ondersoek, juis vanweë die felle kontras wat daar bestaan tussen die kulture en die algemene organisatoriese opset van Japan en SuidAfrika, soos wat mettertyd ook sal blyk.

\section{Organisatoriese doeltreffendheid in Suid-Afrika}

Enige betragting van die Suid-Afrikaanse volkshuishouding skep die indruk van 'n oneindig ingewikkelde mosaïk. Op bykans elke lewensterrein word Suid-Afrika getipeer as 'n land van kontraste, ' $n$ land van uiterstes en 'n land van armoede en rykdom.

Suid-Afrika word dikwels beskryf as ' $n$ jong, lewenskragtige en ontwikkelende land. Terselfdertyd kan gesê word dat Suid-Afrika se probleme in baie opsigte 'n mikro-kosmos van die wêreld se probleme verteenwoordig. Afgesien van talle en uiteenlopende kulturele verskille, bestaan daar ook groot verskille tussen die inwoners met betrekking tot veranderlikes soos inkomste,
H.J.J. Spoelatre

Strool vir Bedryfsleiding, Universiteit van Suid-Afrika, Posbus 392, Pretoria 0001 
status, godsdiens, opvoeding, agtergrond, taal en vermoë. Suid-Afrika worstel verder met talle probleme: 'n uiters heterogene bevolkingsamestelling, lae produktiwiteit, lae ekonomiese groei, werkloosheid, arbeidsomset, ongeletterdheid, groot verskille in die verspreiding van welvaart, kulturele frustrasies en soms politieke onsekerhede, aspekte wat individueel of gesamentlik daartoe bydra om die land se kollektiewe produktiwiteitsyfers en die doeltreffendheid of sukses van sy organisasies te beïnvloed.

Om dus 'n volledige oorsig van die Suid-Afrikaanse ekonomiese milieu te gee, is 'n onbegonne taak. In hierdie artikel gaan dit om 'n vergelyking tussen Suid-Afrika en Japan sover dit organisatoriese doeltreffendheid aangaan. Die veranderlikes of faktore wat dus aandag verdien, hou nóú verband met organisatoriese doeltreffendheid as sodanig.

Hoe suksesvol is organisasies in Suid-Afrika daarin om hulle doelwitte te bereik en om in die proses die vereistes van interne en eksterne individuele of gemeenskaplike bevrediging na te kom? Met ander woorde, in die finale ontleding bly die sukses van enige organisasie steeds afhanklik van die vermoë van die individuele werknemer of bestuurder om verskillende produksiefaktore saam te snoer en doeltreffend (en eties) te benut. Enige benadering tot verhoogde produktiwiteit en of doeltreffendheid in organisasies, moet dus in die eerste plek begin by ' $n$ verandering van individuele aksies, denkprosesse en benadering.

Die doeltreffende bestuur en benutting van arbeid in Suid-Afrika berus merendeels op benuttings- en bestuursbeginsels wat uiteraard Westers van oorsprong is. Die stelling dat bestuursbeginsels in Suid-Afrika Westers van aard is, het min kwalifikasie nodig. Feitlik alle handboeke en aanbevole leesstof wat in die Ekonomiese Wetenskappe aan Suid-Afrikaanse universiteite voorgeskryf word, is Westers van oorsprong.

\section{Indiensneming}

Die doeltreffendheid van die stelsel van indiensneming kan, volgens Flippo ${ }^{2 p p 135-136}$ geëvalueer word in terme van die werksukses van persone wat in diens geneem is. Die werknemer se werksukses kan weer waarskynlik deur kriteria soos produktiwiteit, houding, arbeidsomset, identifikasie met die organisasie en motivering weerspieël word.

Dit wil voorkom asof bedryfsielkundige keuringstegnieke in Suid-Afrika nog nie veel kon vermag om produktiwiteit van arbeid oor 'n breë spektrum te verhoog nie. Kraft en Motsepe ${ }^{3, p 190}$ berig dat die produktiwiteit van stedelike Swartes in die tydperk 1960-1971 slegs met $2,1 \%$ toegeneem het, terwyl hulle gemiddelde salarisse met $5,5 \%$ gestyg het. Dieselfde skrywers haal statistiek aan wat daarop dui dat die arbeidsomset van Blankes in die metaalbedryf in $1973118 \%$ was. Dié van Swartes was $82 \%$ en dié van Kleurlinge $102 \%$. Afwesigheid in die skoenbedryf in 1974 was relatief laer vir Swartes, naamlik $4,9 \%$, teenoor $5,1 \%$ vir Blankes en 5,5\% vir Kleurlinge. In ongeveer dieselfde tydperk het wetenskaplike personeelbestuur en die gepaardgaande gebruik van keuringstegnieke toegeneem (Langenhoven \& Verster ${ }^{4}$ ).

Die doeltreffende en wetenskaplike werwing en indiensneming van personeel berus volgens Flippo ${ }^{2, p p ~ 109-150}$ op die toepassing van werkontledinginligting in die werwing- en keuringsproses, asook op behoorlike beplanning aan die hand van personeelbehoefte- en omsetsyfers. Werkontleding is volgens Tiffin en McCormick ${ }^{528}$ gewortel in die aanvaarding van die konsep van individuele verskille. Die sukses van die toepassing van werksontledinginligting in keuring hang dus af van die vermoë van die bedryfsielkundige om individuele veranderlikes en omgewingsveranderlikes doeltreffend te kombineer.

Met betrekking tot die sukses van die metode van werksontleding as fundamentele tegniek vir doeltreffende werwing, keuring en opleiding, beweer Jones en De Cotiis ${ }^{6, D 00}$ dat daar wydverspreide ontevredenheid in die VSA oor huidige werksontledingsprogramme bestaan. Hulle wys op die tekortkominge van die werksontledingmetode weens die gebrek aan menseverhoudinginligting en die probleme om die metode vir snelle ontwikkeling op tegnologiese gebied te benut.

Die keuring van personeel (en ook ander bedryfsielkundige funksies) het in die Weste al tot so 'n hoogs gespesialiseerde wetenskap ontwikkel, dat daar byvoorbeeld van bedryfsielkundiges in Suid-Afrika verwag word om hulle by die Suid-Afrikaanse Mediese en Tandheelkundige Raad te registreer. Hulle funksies word as so kompleks en gespesialiseerd beskou dat die publiek teen enige kwaksalwery op hierdie gebied beskerm moet word. Die feit dat daar so 'n hoë mate van professionele bevoegdheid vir hierdie funksie vereis word, mag ook ' $n$ aanduiding wees van die problematiek wat aan die kwessie van doeltreffende keuring gekoppel is. In skrille kontras hiermee, sal later daarop gewys word dat die vak Bedryfsielkunde feitlik nie in Japan bestaan nie, maar dat organisasies in Japan selde dieselfde mate van probleme met bv. arbeidsomset, lae produktiwiteit en afwesigheid ondervind.

\section{Opvoeding en opleiding}

Die primêre vraag hier is hoe doeltreffend opvoeding en opleidingsaksies in Suid-Afrika is in terme van die verhoogde produktiwiteit wat daardeur veroorsaak word en in terme van die kwaliteit en kwantiteit van die produkte wat gelewer word. Biesheuvel ${ }^{7, p 3}$ rapporteer byvoorbeeld dat 37\% uit 'n groep van 18000 dienspligtiges in die Weermag nie verder as standerd 7 gevorder het nie en dat $70 \%$ van hierdie groep ook nie beoog om hulleself verder te bekwaam nie.

Die Buro vir Marknavorsing ${ }^{8}$ aan die Universiteit van Suid-Afrika rapporteer in 1979 dat organisasies in die Pretoria-Witwatersrand-Vereeniging-gebied van mening is dat gemiddeld $24 \%$ van alle Blanke en Swart personeel tot hulle beskikking van goeie kwaliteit is; dat $46 \%$ bevredigend is en dat $29 \%$ van swak gehalte is.

Gugushe ${ }^{9 . p^{145}}$ beweer dat die Suid-Afrikaanse Regering sedert 1974 verskeie pogings aangewend het om die produktiwiteit van Swart werkers met behulp van opleidingsprogramme te verhoog. Die skrywer beweer egter dat daar in 1976 steeds slegs 8,5\% Swart leerlinge in sekondêre skole was teenoor die $35,5 \%$ by Blankes. Daar bestaan ook volgens Gugushe $e^{9 . p p} 148-154$ talle probleme met die skoling van Swartes, soos byvoorbeeld die koste van skoling, 'n onderwyserstekort, 'n skooltekort, die kwessie van taalmedium, werkreservering en sekere politiek-staatkundige beperkings. Gugushe ${ }^{9, p^{158}}$ beweer 
verder dat Suid-Afrika in 1990 ongeveer 1400000 opgeleide Swartes vir sogenaamde witboordjieposte sal benodig en dat 'n uitgebreide program vir die ontwikkeling en opleiding van Swartes in Suid-Afrika nodig is. Volgens die 1970-sensus het 104511 Blankes, 1096 Kleurlinge, 2392 Asiërs en slegs 1411 Swartes in SuidAfrika oor universiteitsgrade beskik.

Dit wil gevolglik voorkom of Suid-Afrika 'n besondere probleem op die gebied van die opvoeding het. Afgesien van die emosionele en politieke kleur wat die hele kwessie van Swart opvoeding die afgelope aantal jare gekry het, oefen dit ook ' $n$ belangrike invloed op ekonomiese groei en produktiwiteit uit. Organisasies verkies in die meeste gevalle skynbaar steeds om die opleidingsfunksie aan skole en universiteite oor te laat. Suid-Afrika is aan die een kant opgeskeep met 'n dringende werkloosheidprobleem en aan die ander kant word talle poste skynbaar ongevul gelaat vanweë 'n tekort aan voldoende beskikbare opgeleide en opgevoede werkers.

Ook wat bestuur aanbetref, is opleiding in die eerste plek blykbaar gerig op ' $n$ individuele benadering; met ander woorde meer klem word skynbaar gelê op individuele suksesbehoeftes as wat die doelwitte van organisasies in gedagte gehou word ('n probleem wat altyd sal bestaan waar die opleidingsfunksie van organisatoriese funksies geskei word.)

\section{Die stelsel van vergoeding}

Die doeltreffendheid van enige vergoedingstruktuur word bepaal deur die mate waarin dit slaag om die werker se tevredenheid te verhoog en om hom meer produktief te maak sodat dit tot die optimale doelbereiking van die organisasie lei. Langenhoven en Verster ${ }^{10, p 2}$ vind dat werkgewers sê hulle vergoed hulle werknemers volgens meriete, maar dat die definiëring van die konsep 'meriete' baie verskil en moeilik is om 'in absolute sin te bepaal'. Die skrywers tref baie groot verskille in salarisse van werkers binne dieselfde posgroepe met dieselfde opleiding en op dieselfde organisatoriese vlak aan. Verder bevind hulle dat nie slegs posvereistes nie, maar ook persoonlike hoedanighede soos ouderdom, kwalifikasies, dienstyd en meriete 'n redelike hoë verband met salarisvlak toon.

Backer ${ }^{11}{ }^{3}$ bevind dat salarisse en lone die primêre motiveerders in die geval van Swartes in Suid-Afrika is. Dit bring die vraag na vore of Westerse beginsels van motivering inderdaad by Swartes ter sprake kan wees. Die emosie wat deesdae betrokke is by die kwessie van Swart lone laat die vraag ontstaan in watter mate die konsep van meriete in salaris- en vergoedingbepaling deur Swartes in Suid-Afrika aanvaar word en of gesagstrukture in die Swart gemeenskappe nie in konflik met die merietebeginsel is nie. Ook wat bevordering as vergoeding vir meriete betref, beïnvloed die subjektiwiteit van die konsep die geloofwaardigheid van 'merietegefundeerde' optrede van bestuur.

Dit wil dus voorkom of die kwessie van individuele meriete een van die belangrikste probleemgebiede is waarmee personeelbestuur te kampe het - veral in heterogene gemeenskappe. Dit word betwyfel of vergoedingstelsels in Suid-Afrika veel tot verhoogde doeltreffendheid kan bydra en of die sogenaamde meriete- basis nie eerder 'n nadelige uitwerking op produktiwiteit het nie.

\section{Motivering, werktevredenheid en leierskap}

In Suid-Afrika is al teenstrydige resultate met navorsing oor motivering en werktevredenheid verkry. Terblanche ${ }^{12 \mathrm{p} 61}$ het byvoorbeeld 'n algemene hoë vlak van werktevredenheid by natuurwetenskaplikes gevind. Hy bring sy gevolgtrekking in lyn met ander studies in die VSA wat aangetoon het dat die beoefenaars van beroepe met 'n relatief hoë status in die algemeen tevrede met hulle werk is. In teenstelling hiermee, toon Van Breda en Langenhoven ${ }^{13} \mathrm{p}^{18}$ aan dat lae produktiwiteit en motivering van Swart en Kleurlingwerknemers een van die ernstigste probleme is waarmee werkgewers te kampe het. Kraft en Motsepe ${ }^{3 p}{ }^{191}$ toon aan die hand van 'n literatuuroorsig aan dat laer orde-behoeftes (op Maslow se hiërargie) die belangrikste vir Swartes in 'n vroeë stadium van kulturele ontwikkeling is. Vir Swartes in die lae range van die organisasie, blyk finansiële vergoeding die primêre bevrediger en motiveerder te wees; met ander woorde fisiologiese behoeftes is dominant. Namate Swartes Westersgekultiveerd en verstedelik raak, kan daar van werktevredenheid in terme van hoër-orde behoeftes begin praat word. 'n Groot uiteenlopendheid bestaan dus in Suid-Afrika sover dit motiveringsdinamiek en werktevredenheid van sy ekonomies-bedrywige bevolking aangaan.

Om doeltreffendheid van bestuur in Suid-Afrika te beoordeel is baie moeilik en dit varieer buitendien ook seker heelwat van organisasie tot organisasie. Nogtans kan daar met redelike sekerheid aanvaar word dat 'n bestuurder in die Weste en in Suid-Afrika oor sekere vermoëns of eienskappe moet beskik ten einde as doeltreffend bestempel te word. Hicks ${ }^{14} \mathrm{p}^{121}$ sonder die volgende doeltreffendheidsvereistes hier uit: Die vermoë om te skep, te beplan, te organiseer, te motiveer, te kommunikeer en te beheer. Dit wil voorkom of bestuur in die Weste en in Suid-Afrika oor 'n definitiewe beherende en besluitnemende funksie beskik. Hoewel desentralisasie van besluitneming telkens in bestuurshandboeke verkondig word, kan aanvaar word dat alle werklike beslissings gewoonlik steeds deur bestuur geneem word. Deelname in besluitneming word meestal bloot as ' $n$ tegniek in motivering en integrasie van doelwitte beskou (Flippo $^{2, p 353}$ ).

Bestuursdoeltreffendheid word waarskynlik weerspieël in die wyse waarop die organisasie sy doelwitte bereik en terselfdertyd aan die eise van verskillende belangegroepe voldoen. Bestuur in Suid-Afrika het met relatief groot en unieke probleme te kampe. In die lig van hierdie talryke probleme is dit nie onmoontlik dat hulle beter vir hulle taak toegerus mag wees as bestuur in menige ander lande nie. Te midde van Suid-Afrika se probleme is veel al tot stand gebring. Nogtans wil dit voorkom of daar steeds geweldig ruimte vir verbetering en verhoging van doeltreffendheid op veral die gebied van die benutting van Swart werkers bestaan. Beter benutting van hierdie groot en groeiende gedeelte van die land se arbeidsmag, mag moontlik ' $n$ heeltemal nuwe benadering tot bestuur impliseer; ' $n$ benadering wat tot groter aanvaarding van en identifikasie met organisatoriese doelwitte kan lei. 


\section{Vakbondstelsel}

In Suid-Afrika is die hele aangeleentheid van vakbonde in 'n staat van ontwikkeling en 'n mate van onsekerheid gehul. Na die voltooiing van die werk van die Wiehahnkommissie is die vrye reg tot vakbondaffiliasie aan Swart werkers verleen, met enkele uitsonderings. Dit het moontlik tot gevolg gehad dat daar in 1980 'n aantal werkstakings dwarsoor Suid-Afrika ervaar is. Dit wil egter nie sê dat stakings vroeër nie aan die orde van die dag was nie. Kraft en Motsepe, $p 208$ rapporteer byvoorbeeld dat 1157000 manure in 1973 in Suid-Afrika verlore gegaan het as gevolg van werkstakings.

Dit behoort interessant te wees om die ontwikkelinge op die gebied in Suid-Afrika dop te hou. Die aard van die ontwikkeling van die vakbondbeweging mag ook' $n$ aanduiding wees van die algemene mate van uiteenlopendheid van die belange van arbeid en die belange van organisasies in Suid-Afrika.

\section{Organisatoriese doeltreffendheid in Japan}

\section{Arbeidsprioriteit}

Personeeladministrasie, die algemene stelsel van indiensneming van arbeid, instandhouding van arbeid en prestasie van arbeid as produksiefaktor in Japanse organisasies, geniet deurgaans die besondere aandag van verskeie navorsers oor doeltreffendheid en sukses van die Japanse ekonomie. Dit sou waarskynlik gepas wees om die prioriteit wat die hele kwessie van arbeid en personeel in Japanse organisasies geniet, as eerste unieke en andersoortige kenmerk of element van doeltreffendheid uit te sonder.

In feitlik al die bronne wat handel oor determinante van groei en sukses in Japan, word aan die arbeidsaspek 'n besondere plek toegeken (Drucker ${ }^{15, \text { p } 110}$; Ichimura ${ }^{16, p}$ ${ }^{43}$; Rehder ${ }^{17, p}{ }^{21}$ ) terwyl ondersteuning vir die argument van 'n arbeidsprioriteit ook verkry word uit Johnson ${ }^{18, p 2}$, wat in 'n vergelykende empiriese studie gevind het dat Japanse organisasies meer organisatoriese middele in die vorm van opleiding, leiding, aandag en maatskaplike hulp in hulle werkers belê as Amerikaanse organisasies. Voorts verduidelik Noda ${ }^{19}$, p. 140 dat menslike aspekte in 'n onderneming 'n groot deel van bestuur se tyd in beslag neem en dat hierdie prioriteit ook duidelik word uit die uitgebreide stelsel van byvoordele van werkers, 'n persoonlike aard van betrokkenheid van werkers (teenoor 'n onpersoonlike betrokkenheid by Westerse organisasies) en die groot klem op die organisasie se 'atmosfeer', sy beeld en die organisasie van werkers se vrye tyd en selfs van hulle gesinslewe.

Indiensneming (die lewenslange indiensnemingstelsel) ('shushin koyo')

Die bekende Japanse beginsel van lewenslange indiensneming (hierna na verwys as L.L.I.) kom in kort daarop neer dat ' $n$ werknemer tot met sy aftrede, nooit die diens van sy werkgewer sal verlaat nie of deur sy werkgewer uit sy diens ontslaan word nie.

Abegglen ${ }^{20 . p .75}$ toon aan dat 'n arbeidsomset van 3,6\% oor 'n periode van vyf jaar, vir 'n groot maatskappy in Japan normaal sou wees. Indien enige organisasie egter 'n arbeidsomset van $10 \%$ per jaar sou ondervind, sal dit beteken dat daar iets drasties met die organisasie verkeerd is. 'n Ontleding van statistiek oor arbeidsomset maak dit duidelik dat daar weinig verandering sedert 1976 ingetree het, ondanks die voorspellings deur talle Amerikaanse skrywers dat dit slegs 'n kwessie van tyd is voordat die stelsel verander na iets meer 'Amerikaans', waar arbeidsmobiliteit hoog is en talle mense gereeld van werk verwissel en waar industriële gemeenskappe toenemend dieselfde word (Fox, ${ }^{21, \text { pp. } 76-85}$; Karsh \& Cole, ${ }^{22, \text { p.62; }}$;offler ${ }^{23}$ ).

Lewenslange indiensneming en gepaardgaande arbeidsomsetsyfers het egter slegs betrekking op dié gedeelte van die arbeidsmag wat permanente aanstellings by hulle organisasies het (ongeveer $35-40 \%$ ). Maatskappye stel verder talle werkers op 'n tydelike basis aan. Dit is ook steeds oorwegend die gebruik dat vroulike werknemers die diens van hulle werkgewers verlaat sodra hulle hulle in 'n huwelik begewe. Gevolglik word hulle telkens as 'tydelike' werkers beskou. Die 'permanente kern' (ongeveer $35-40 \%$ ) bestaan gevolglik gewoonlik uit manlike werknemers. Die uitgawes verbonde aan hulle salarisse en lone verteenwoordig ook 'n vaste koste-item in die finansiële state van die Japanse organisasie.

Die voordele verbonde aan hierdie stelsel is veral geleë in

- die afwesigheid van arbeidsomset van dié werkers wat vir die voortbestaan van die organisasie die belangrikste is;

- die voordele wat met 'n lang verbintenis gepaard gaan, byvoorbeeld in opleiding, toewyding, en toegewyde belang by alle besluite van die organisasie, snelle aanpassingsvermoë ('n vereiste ten einde voortbestaan in 'n mededingende mark te verseker), individuele groeipotensiaal, ontwikkeling van idees en groepsamehorigheid;

- werwing wat slegs vanaf kolleges, skole en universiteite geskied, omdat alleenlik 'vars' werkers sonder vorige ervaring in diens geneem word;

- 'n plasingsbuigbaarheid en

- doeltreffender mannekragbeplanning.

Die spesifieke ontstaan van die LLI-stelsel is volgens Nakayama ${ }^{24 . ~ p .84}$ en 'n verslag van die Organisasie vir Ekonomiese Samewerking en Ontwikkeling (OECD, ${ }^{25, \text { p. } 15)}$ ) te danke aan die gesamentlike besluit in die twintigerjare van die groot 'Zaibatsu' (die reuse korporasies soos Mitsui, Mitsubishi en Sumitomo) om slegs skool- en/of universiteitsverlaters permanent in diens te neem nadat probleme tydens die industrialisasie met die behoud van opgeleide werkers ontstaan het. Dit is ook duidelik van Nippon Keizai Shinbun ${ }^{26, p .3}$ dat die stelsel kwalik totaal kan verkrummel voordat hierdie indiensnemingspraktyk (om slegs skool- en universiteitsverlaters in diens te neem) vaarwel toegeroep is nie. Daar moet moontlik wel aanvaar word dat sekere eienskappe van die kultuur (bv. die arbeids- en gesagbeskouing) ook veroorsaak het dat hierdie stelsel geredeliker aanvaar is.

\section{Bedryfsopvoeding en -opleiding}

Die opleidingsfunksie is een van die heel belangrikste funksies van personeeldepartemente in Japanse organisasies. Opleiding is vir die Japanner in die eerste plek skoling in 'organisasiebewustheid' en lojaliteit. Die resultaat van hierdie opleiding is telkens 'n groot mate van buigbaarheid en gereedheid om tegnologiese vernuwing in die 
organisasie te aanvaar. Hierdie toewyding beteken volgens Ballon ${ }^{27}$, p.74 nie 'n slaafse aanvaarding van elke gier van bestuur nie. Hy wys daarop dat bestuur in Japan nie die organisasie is nie, maar dat dit daar is vir die organisasie.

Omdat organisasies in Japan nie elders op die arbeidsmark opgeleide en ervare werkers kan bekom nie (vanweë die lewenslange indiensnemingverhouding), is dit van die grootste belang dat hulle self vir die opleiding en ontwikkeling van hulle personeel voorsiening maak.

Opleiding as bron van organisatoriese doeltreffendheid kan waarskynlik nie onafhanklik van die metode van werkbeskrywing en taakomlyning in Japan bespreek word nie. Die feitlik algehele afwesigheid van 'uiterlike personeelkontroles', soos posbeskrywings, posspesifikasies en posanalises in Japan, is goed bekend (Dore, ${ }^{28, ~ p .71 ;}$ Drucker, ${ }^{15 . \text { p.117 }}$ Fox ${ }^{21, p .78}$, en aangesien 'n persoon se verantwoordelikheid in die algemeen swak gedefinieer is, kan 'n evaluasie van vermoëns kwalik 'wetenskaplikobjektief' uitgevoer word (Kitagawa, ${ }^{29, p .4}$ ).

Hierdie eienskappe bemoeilik verder die beweging vanaf een organisasie na ' $n$ ander, en afgesien daarvan dat dit die LLI-gebruik versterk, beteken dit dat talent en vermoëns eksklusief aan elke organisasie gelaat word om te ontwikkel. Kitagawa ${ }^{29, p .4}$ beweer dat individuele bevoegdhede op hierdie wyse makliker raakgesien word en dat die interne organisasie-opvoeding beter beplan kan word.

Die Japanse stelsel van werkrotasie (Clark, ${ }^{30, p .57}$ ) waarvolgens werkers teen om en by $10 \%$ per jaar na ander departemente geroteer word, is 'n praktiese uitvloeisel van die beginsel van die opleiding van generaliste eerder as spesialiste. Dit dien ook as 'n verduideliking vir die sielkundige kontrak tussen werker en werkgewer, asook van die siening van die werker dat hy 'n organisasie-verbintenis eerder as 'n pos-verbintenis aangaan.

Drucker $^{15, \text { p.110-112 }}$ onderskei verder tussen voortdurende ('continuous') opleiding in Japan en voortgesette ('continuing') opleiding in die Weste, waar laasgenoemde impliseer dat opvoeding en opleiding primêr deur instansies onafhanklik van die organisasie gedoen word. Voortdurende opleiding impliseer feitlik uitsluitlik herhaaldelike opleiding binne die organisasie en vir die organisasie.

Dit blyk dat, hoewel senioriteit volgens diensjare mag geskied, verantwoordelikhede telkens op 'n heeltemal verskillende wyse toegeken word (Clark, ${ }^{39}$ ) en dat 'n relatief junior werker hom in 'n posisie mag bevind waar hy hoogs verantwoordelike funksies moet verrig en geen spesiale vergoeding daarvoor ontvang nie. Clark wys daarop dat die organisatoriese lewe onder dié stelsel veel 'makliker' is en dat dit minder spanning veroorsaak - 'n belangrike faktor in die lig van die LLI-stelsel. Ervaring word ten volle erken en elkeen kry die geleentheid om sy vermoëns te bewys.

'Outomatiese' bevordering geskied tot ongeveer op 40-jarige ouderdom (vir permanent personeel). Dit is logies dat al die permanente personeel nie daarná bevordering kan kry nie, behalwe as die organisasie buitengewoon uitbrei. Nogtans bestaan daar meer as net een graderingsmetode in Japanse organisasies, waarvolgens diensjare erken word en waaraan sekere statustitels geheg word (Clark, ${ }^{30,0.121}$ ).

Hoewel die frustrasie na die ouderdom van 40 jaar van 'n groep LLI-werkers soms groot mag wees, is hulle in elk geval seker van hulle poste en weet hulle dat hulle nie deur jonger werkers vervang sal word nie. Bowendien verskil die aard van bestuurspligte in Japanse organisasies ook soveel van dié in die Weste, dat heeltemal ander eise aan Japanse bestuur gestel word, wat waarskynlik nie naastenby soveel spanning veroorsaak nie en in elk geval weinig of geen eise van individuele besluitneming insluit nie. Later sal hieraan meer aandag gegee word.

Opvoeding (en nie handeldryf) is Regeringsprioriteit in Japan en die belangrike plek wat opvoedingsuitgawes in die Japanse nasionale begroting inneem, is gefundeer in die vaste geloof dat daar 'n direkte verband tussen opvoedingbesteding en ekonomiese groei bestaan.

Opleiding en opvoeding verkry veral 'n besondere plek as faktor in die organisatoriese doeltreffendheidsvlak in Japan wanneer dit nie in isolasie bespreek word nie, maar wanneer dit gesien word as 'n metode waarvolgens die LLI-stelsel verder verryk en uitgebou word. Tesame met LLI, verander opleiding in lewenslange opleiding van dié werkers wat vir die organisasie die belangrikste vir sy voortbestaan en doeltreffendheid is. Die nasionale opvoedingstelsel verseker verder 'n opgevoede arbeidsmag wat algemeen in uniform is en wat minder differensiasie in opvoeding toon as in enige ander land. Differensiasie word eerder aan die organisasie self oorgelaat om te ontwikkel.

\section{Die stelsel van bevordering}

Volgens Westerse standaarde word die senioriteitsbevorderingstelsel (nenko joretsu), wat in Japan oral gevolg word, waarskynlik nie as doeltreffend beskou nie. Karsh

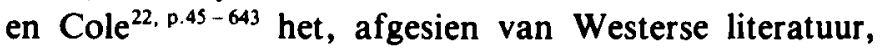
selfs Japanse skrywers aangehaal wat aandring op die verandering van die stelsel as gevolg van sy ondoeltreffendheid. Die 'nenko'-bevorderingstelsel moet egter saam met die stelsel van LLI en opleiding gesien word. Dit is dus van belang om die stelsel, afgesien van onmiddellike motiveringsaspekte, ook op grond van langtermynkriteria te beoordeel. Vir die organisasie beskik dit oor die voordele dat dit doelmatige loopbaan- en langtermynbeplanning vergemaklik (Hayashi, ${ }^{31, p .224}$ ), dat bestuur opvolgers kan kweek en opleiding met bevordering kan sinchroniseer (Kitagawa, ${ }^{29}$, p.5) en dat dit interpersoonlike konflik tot 'n minimum beperk.

Ballon $^{27, p .126}$ verduidelik dat die uitgebreide aard van hierdie voordeel 'n verdere aanduiding van die hegtheid van die verhouding tussen werker en organisasie is in Japan. Japanse organisasies se verantwoordelikheid jeens hulle werknemers strek skynbaar veel verder as net die betaling van die vereiste salarisse, pensioene en mediese voordele.

Deur 'n ontleding van die kriteria wat Japanse werkgewers gebruik om hulle werknemers te vergoed, kan 'n goeie begrip van hulle prioriteite en hulle sienings van arbeidsdoeltreffendheid verkry word. Dit is duidelik dat salaris aanvanklik nie as verwant aan werkprestasie beskou is nie. Salaris is bloot die teenprestasie van 'n lewenslange verbintenis, en vir lojaliteit aan die organisatoriese familie. Later is klein, maar nie-kritieke wysigings in die salarisstelsel ingebring, waarskynlik in navolging van Westerse idees, om te dien as middel tot produktiwiteitbevordering. Volgens Ballon ${ }^{32}$ en andere, word dit egter 
selde werklik aan prestasie gekoppel, terwyl 'prestasie' bowendien telkens in terme van sake los van prestasie gedefinieer word.

Die regverdigheid van die skaal, die relatief eweredige verspreiding van inkomste deur die bevolking en die gereelde jaarlikse lewenskosteaanpassings van salarisse na aanleiding van vakbondonderhandelings, beteken dat die salarisstelsel minder as in ander lande ' $n$ bron van irritasie en ongelukkigheid is. Dit is 'n gegewe entiteit en bly konstant weens die lewenslange verhouding tussen werkgewer en werknemer. Dit bevestig en versterk slegs hierdie band en dit beloon ook hierdie verwantskap.

Om enige bestaande stelsel te verander moet daar ' $n$ behoefte vir sodanige verandering bestaan. Volgens Jetro $^{33, p .8}$ is daar min of geen druk vir verandering nie, omdat alle werkers weet dat beloning in terme van posisie uiteindelik tog bekom sal word en weet hulle in elk geval dat niemand van buite aangestel sal word in 'n senior betrekking nie.

\section{Vergoeding}

Dit is moeilik om enige vergelyking tussen die Westerse en Japanse salarisstelsels te tref. Japan se basiese salarisse is nie noodwendig veronderstel om verband met doeltreffendheid te hou nie en daar word geen poging aangewend om dit in verband te bring nie. Die Japan Times ${ }^{34, p p .8-9}$, beweer dat salarisse in Japan die afgelope jare relatief minder met organisatoriese inkomstes verband gehou het as elders in die wêreld.

Basies kom die vergoedingstelsel in Japan daarop neer dat feitlik alle permanente werkers op een skaal vergoed word. Hierdie skaal het sekere limiete, wat aan posisies gekoppel is, andersins vorder 'n werknemer gewoonlik deur die skaal deur jaarlikse klein kerfaanpassings. Elke jaar, gedurende die lente-maande, word daar ook lewenskoste-aanpassings aan die hele vergoedingstruktuur gemaak na aanleiding van gesamentlike vakbondaksies. Die salarisskaal is dus direk aan senioriteit gekoppel en nie aan meriete nie. Verder voorsien Japanse werkgewers ook 'n wye reeks van byvoordele vir sy werknemers.

\section{Bestuursdoeltreffendheid}

In Tabel 1 word 'n uiteensetting gegee van enkele funksionele verskille van bestuur in Japan en Suid-Afrika.* Rehder $^{17 .}$ p.25 is van mening dat daar belangrike verskille in basiese bestuursdoelwitte bestaan, dat doeltreffendheidskriteria gevolglik verskil, en dat 'n vergelyking van doeltreffendheid onmoontlik is. Rehder ${ }^{17}$. p.25 beweer byvoorbeeld dat aansien ('face') prioriteit het bo wins in die Oriënt. Die Japanse maatskappy word gevolglik soms teen 'n uiters lae winsmarge bedryf om sy markaandeel ('face') te behou.

In die V.S.A. is opbrengs gewoonlik die eerste kriterium vir enige sakeprojek en is korttermynvoordele van groter belang as langtermynvoordele. Met die LLI-stelsel as verdere behoudende faktor, is oorlewing en 'n gevolglike langtermynvisie in Japan die primêre doel van bestuur. Ter ondersteuning hiervan verduidelik Drucker $^{15, \text { p. } 234}$ dat die maksimalisering van wins geen sin vir enige Japanse sakeman het nie. Daarin is vir sy organisasie en vir hom geen voordeel gesetel nie. Hieruit volg dit dat aandeelhouers van Japanse organisasies ook eerder beperkte opbrengste as hoë risiko verkies.

Tabel 1 Bestuurspraktyk in Japan en Suid-Afrika

\begin{tabular}{rc}
\hline JAPANSE BESTUUR & WESTERSE BESTUUR \\
\hline Lewenslange indiensneming. & $\begin{array}{l}\text { Word vir spesifieke take in diens } \\
\text { geneem; wanneer die take afge- }\end{array}$
\end{tabular}

Indiensneming berus op eksamens, skool en universiteitsbande, familie.

Organisasiestruktuur vaag omskryf.

Poste, pligte, verantwoordelikhede vaag omlyn.

Vergoeding gebaseer op senioritiet, opvoedingspeil en gesinsverantwoordelikhede.

Bevordering ' $n$ funksie van diensjare en ouderdom.

Paternalistiese sorg oor werknemers.

Werknemer verwag organisasie se betrokkenheid by sy hele gesin.

Werknemer aan ' $n$ onderneming toegewy.

Vakbonde wat organisasie se finansiële toestand op die hart dra.

Besluitneming volgens konsensus.

Opleiding 'n primêre organisasiefunksie.

*Bron: Rehder ${ }^{17}$, p.25

Rehder $^{17, p .24}$ is egter van mening dat die kultuurgebondenheid van die Japanse bestuurstelsel nie oorbeklemtoon moet word nie. Hy wys daarop dat baie Japanse organisasies wat hulle in die V.S.A. gevestig het, hulle stelsel in sekere opsigte by die Amerikaanse lewenswyse aangepas het, maar nogtans hulle totale en opregte besorgdheid en betrokkenheid by hulle werknemers behou het. Hulle is nie net besorg oor hulle werkers se werkprestasies nie, maar ook oor hulle totale lewenskwaliteit. Daarom word werkers ontwikkel en betrek by besluitneming.

Die groepbetrokkenheid van die Japanse werker van alle vlakke en veral ook bestuur, word goed geillustreer deur die 'ringi'-stelsel. Die stelsel word deur Glazer ${ }^{35,} \mathrm{p} 88$ en talle ander skrywers deeglik bespreek. 'Ringi' is die formalisering van die metode van besluitneming deur konsensus en beskryf die verskillende stappe en kanale van enige formele besluit in Japanse organisasies. Volgens hierdie stelsel kan geen besluit sonder die konsensus van almal wat deur die besluit geraak word, geneem word nie. Die steisel is reeds deur onder andere Clark $^{30, p}{ }^{126}$, Nakane ${ }^{36, p 68}$ en die Organisasie vir Ekonomiese Samewerking en Ontwikkeling OECD ${ }^{25, p} 29$ as 'n belangrike en doeltreffende stelsel erken. In die verslag van die $O E C D$ word dit as die teorie $Y$ van Japan beskryf. Japan kan as praktiese illustrasie vir McGregor ${ }^{37}$ se teorie dien, volgens die verslag. Clark ${ }^{30, p_{128}}$, beweer dat kollektiewe bestuur in die lang termyn minder foute maak deur middel van 'ringi'-besluitneming. Besluitneming vind ook meer egalig plaas. Hierdie stelsel is in ' $n$ groot mate afhanklik van die bereidwilligheid om te erken dat verantwoordelikheid kollektief gedra word en 
dat besluite noodwendig meer as een mens betrek. Verder is dit volgens Clark ${ }^{30, p 129}$ belangrik om te let op die homogeniteit van die arbeidsmag en die kleiner onderskeid tussen bestuur en werkers as in die Weste. Bestuur se taak is dus eerder om toe te sien dat besluite geneem word as om dit self te neem.

\section{Individuele werkinset}

In terme van sekere bekende Westerse kwantitatiewe ekonomiese kriteria soos opbrengs per capita, BNP per capita, werkure, ongelukke, afwesigheid, en produktiwiteit wil dit voorkom asof individuele lede van organisasies in Japan in die algemeen meer doeltreffend is as hulle Westerse of Suid-Afrikaanse kollegas. Met betrekking tot die meer kwalitatiewe, is vergelykings veel moeiliker, maar nogtans kan die afleiding gemaak word dat die groter betrokkenheid, die skynbaar groter deelname in besluitneming en die groter groepsdeelname ook sekere kwalitatiewe voordele vir organisasies inhou. Dit wil ook voorkom of die Westerse alternatief van werker-individualisme, werker-humanisme en rigiede organisasietrukture nog nie daarin kon slaag om verskille in kollektiewe statistiek oor produktiwiteit tussen Japan en die Weste uit te wis nie.

\section{Die vakbondstelsel}

Die vakbondstelsel in Japan is reeds vir 'n geruime tyd 'n onderwerp van bespreking in die Weste. Besonderhede van die werking daarvan, die aard, die administrasie, bedinging, wetgewing en werkstakings word deeglik behandel deur onder andere Ballon ${ }^{27}$, en Dore ${ }^{18}$. 'n Aantal kenmerke van die stelsel mag moontlik met organisatoriese doeltreffendheid in verband gebring word, naamlik:

- Die onderneming-gebonde aard van vakbonde wat veroorsaak dat hulle '. . . direct their efforts to the development of the industry which is the basis of their life' (Jidoosharoren ${ }^{38, ~ p ~}{ }^{13}$ ).

- Die feit dat stakings selde meer as een of twee dae lank duur (Hanami ${ }^{39,}$ p 206 ).

- Uit 'n ontleding van vakbondaktiwiteite, wil dit voorkom of vakbonde 'n veel meer ondersteunende funksie in Japan vervul as in die Weste, aangesien die organisasie se voortbestaan nooit werklik bedreig mag word nie (dit sou persoonlike vernietiging beteken vanweë die LLI-stelsel).

- Stakingstye word selde so gekies dat dit werklik die produksieproses ontwrig (Ballon ${ }^{40, p 5}$ ).

- Tussen 1969 en 1979 het 0,13 dae per werknemer in Japan verlore gegaan vanweë vakbondaktiwiteite, 0,67 in die V.S.A., 0,48 in Brittanje, 1,72 in Italië en 0,07 in Wes-Duitsland. In Japan egter, met sy relatief min vakansieverlof per jaar, en met inagneming van die keuse van tyd van stakings, beteken dit steeds dat relatief min werklike produksietyd vanweë stakings verlore gegaan het. (Okamoto'1, p s).

\section{Slot}

Dit wil voorkom asof daar in Japan 'n besondere prioriteit ten opsigte van arbeid in organisasies bestaan. Hierdie prioriteit word versterk deur die Staat in Japan se prioriteit in opvoeding asook in die lewenslange indiensnemingstelsel wat allerweë gevolg word.

Die hegte en lewenslange verbintenis tussen werknemer en organisasie het skynbaar ook ' $n$ belangrike invloed op die opleidingsbenadering, op die aktiwiteite van werknemers en bestuurders. Dit het ook blykbaar'n heilsame uitwerking op motivering en produktiwiteit van individuele werknemers. Die intensiteit van die interafhanklikheid tussen organisasie en werker noop die vakbond om veel meer verantwoordelik en ondersteunend op te tree.

Alhoewel daar waarskynlik groot kulturele verskille tussen Suid-Afrikaners en Japanners mag bestaan, moet die verskoning vir relatiewe ondoeltreffendheid nooit slegs aan kultuur en kulturele verskille toegedig word nie. Deur die besluit van groot organisasies om slegs skool- en universiteits-verlaters in diens te neem in Japan en die vroeë twintigerjare, het hulle 'n besondere verantwoordelikheid aan die dag gelê. 'n Verantwoordelikheid om na hulle werknemers se ontwikkeling en welvaart om te sien, tot die dag van hulle dood. Hierdie verantwoordelikheid word dan ook deur lojaliteit en toewyding van werknemers in Japan beloon. Het groot Suid-Afrikaanse organisasies al dieselfde mate van volwassenheid bereik, of druis so 'n besluit te radikaal in teen die individualisme van die Blankes in Suid-Afrika?

\section{Summary}

Japan's extraordinary economic success of the past century makes it an ideal source of comparison with South Africa, where organizational and economic effectiveness have, for quite a few decades been problematic.

South Africa is still struggling to improve the effective utilization of a number of production factors; especially that of labour management and productivity. The utilization of manpower is dependent upon Western approaches and methods of procurement, education and training, remuneration, motivation, labour organization and management, of which the effectiveness in practice, is singularly and collectively in doubt.

Japan bases its approach to the utilization of labour largely on placing a particular emphasis on labour as a factor of production. The life-time employment system seems to be the most important fact in labour deployment, which is strengthened by the concept of life-time training and a seniority based remuneration and promotion system. Management's activities in Japan differ largely from those found in Western countries. Decisions are generated at the lowest levels and arrived at by concensus; while management's prime róle is to maintain a dynamic harmony while the group moves to a decision.

Individual work input in Japan is relatively large, and labour unions play an important but supportive róle in the organization's effective functioning. South Africa should realize that 'Western' concepts do not necessarily lead to effectiveness in Africa. The country should realize that the policy regarding labour and labour development according to which the individual, and his development from childhood, receives high priority from government and organizations, has led to the reaping of benefits by all. 


\section{Verwysings}

1. SPOELSTRA, H.I.J. Kulturele determinante van organisatoriese doeltreffendheid in Suid-Afrika en Japan. Ongepubliseerde D.Com proefskrif. RAU, 1980.

2. FLIPPO, E.B. Personnel Management. McGraw-Hill, 1980.

3. KRAFT, R.L. \& MOTSEPE, W.E.O. The urban Black worker. In: Marais, G. \& Van der Kooy, R. (Eds.), South Africa's urban Blacks: problems and challenges. Promedia, Pretoria, 1979.

4. LANGENHOVEN, H.P. \& VERSTER, R. Opname van personeelbestuur in Suid-Afrika. Universiteit van die Oranje-Vrystaat, Departement Bedryfsielkunde, 1969.

5. TIFFIN, J. \& MCCORMICK, E.J. Industrial psychology. Unwin, 1971.

6. JONES, J.J. \& DE COTIIS, T.A. Job analysis: National survey findings. Personn. J., Okt. 1969.

7. BIESHEUVEL, S. The climate of training - its dependence on human relations. National Institute for Personnel Research, 1975.

8. Buro vir Marknavorsing. The infra-structure of growth areas in South Africa. Verslag 71, Universiteit van Suid-Afrika, 1979.

9. GUGUSHE, R.N. Education for free enterprise. In: Marais, G. \& Van der Kooy, R. (Eds.), South Africa's urban Blacks: problems and challenges. Promedia, Pretoria, 1979.

10. LANGENHOVEN, H.P. \& VERSTER, R. Ondersoek na die faktore wat salarisse en lone bepaal. Universiteit van die OranjeVrystaat, Departement Bedryfsielkunde, 1972.

11. BACKER, W. An inter-cultural study of work motivation. Referaat gelewer tydens die 13de Kongres van die Sielkundige Instituut van die R.S.A. Bloemfontein, Oktober, 1974.

12. TERBLANCHE, S.S. Die werktevredenheid van Blanke natuurwetenskaplikes in die R.S.A. Raad vir Geesteswetenskaplike Navorsing, Pretoria, 1973.

13. VAN BREDA, W.W. \& LANGENHOVEN, H.P. Die benutting van nie-Blanke arbeid. Universiteit van die Oranje-Vrystaat, 1972.

14. HICKS, H.G. Management, organizations, and human resources. Selected Readings. McGraw-Hill, 1972.

15. DRUCKER, P.F. What we can learn from Japanese management. Harv. Bus. Rev., Maart-April, 1971.

16. ICHIMURA, S. The challenge of the rising sun. SEAS reprint series. Center for South East Asian Studies, Kyoto University, 1970.

17. REHDER, R.R. Japanese management: an American challenge. Hum. Res. Mgmt., 1979, 18(4).

18. JOHNSON, R.T. Foreign investment and labour. A comparison of Japanese and American firms in the U.S. and Japan. The 1977 Asian Regional Conference on Industrial Relations. Tokio, $15-$ 18 Maart 1977.

19. NODA, K. Big business organization. In: Vogel, E.F. (Ed.), Modern Japanese organization and decision making. Tuttle,
California, 1979.

20. ABEGGLEN, J.C. Management and worker. The Japanese solution. (2de uitgawe). Kodansha: Sophia University, 1975.

21. FOX, W.M. Japanese management: tradition under strajn. Bus. Horizons, Aug. 1977, 20(4)

22. KARSH, B. \& COLE, R.E. Industrialization and the convergence hypothesis. Some aspects of contemporary Japan. J. Soc. Iss., 1968, XXIV(4).

23. TOFFLER, A. Future shock. Pan Books. London, 1970.

24. NAKAYAMA, I. Industrialisation and labour management relations in Japan. Tokio: The Japan Institute of Labour, 1975.

25. O.E.C.D. (Organisasie vir Ekonomiese Samewerking en Ontwikkeling). The development of industrial relations systems. Parys, 1977.

26. NIPPON KEIZAI SHINBUN. The life-long employment system. Tokio, 1977.

27. BALLON, R.J. (Ed.) The Japanese employee. Tokio: Sophia University, 1969.

28. DORE, R. British factory: Japanese factory. Allen \& Unwin, London, 1973.

29. KITAGAWA, K. Management and progress in Japan. The Third International Productivity Congress. Vienna, Okt. 1970.

30. CLARK, R. The Japanese Company. Yale University Press, London, 1979.

31. HAYASHI, K. Corporate management practices in Japanese Multinationals. Acad. Mgmt. J., 1978, 21(2).

32. BALLON, R.J. Japan's salary system: the bonus. Tokio: Sophia University, Socio Economic Institute, 1977.

33. JETRO (Japan External Trade Organisation). Financial and labor practices in Japan. Business Information Series 2, 1974.

34. Japan Times, The. The Japanese Economic Society: where it's heading, 28 Junie 1979.

35. GLAZER, H. The Japanese executive. In: Ballon, R.J. (Ed.) The Japanese employee. Sophia University, en Tuttle, Tokio, 1969.

36. NAKANE, C. Japanese Society, Great Brittain Penguin, 1974.

37. MCGREGOR, D. The human side of Enterprise, McGraw-Hill, 1969.

38. JIDOOSHAROREN. Meet Jidoosharoren: Federation of Japan Automobile Worker's Unions. Tokio, 1976.

39. HANAMI, T. The characteristics of labor disputes and their settlements in Japan. In Social and cultural background of labormanagement relations in Asian countries. Verrigtinge van die 1971 Asiatiese Streekskonferensie oor Nywerheidsbetrekkinge, Tokio, Japan, 1971.

40. BALLON, R.J. Japanese-like industrial relations. Tokio: Sophia University, Socio Economic Institute, 1973.

41. OKAMOTO, H. The union-management relationship at the enterprise level. Jap. Lab. Bull., 1974, 13(7). 